\title{
Mineral-Resource Data Bases
}

\section{Introduction}

Data bases are essential for modern scientific research. The new and exciting work being done in the Mineral Resource Program in the U.S. Geological Survey (USGS) usually begins with the question, "Where are the known deposits?" A mineral-resource data base containing this type of information and more can be useful not just to USGS scientists, but to anyone who needs such data. Users of the data bases from outside the USGS include mining and exploration companies, environmental groups, academia, other Federal Agencies, and the general public.

At present, the USGS has two large mineral-resource data bases, MRDS (Mineral Resource Data System) and MAS (Minerals Availability System). MRDS was built and is maintained by the USGS, and MAS was built and maintained by the Bureau of Mines. In 1996, after the Bureau was abolished, MAS was transferred to the USGS.

The two data bases were compiled for different purposes and contain very different information. For instance, MAS contains information on costs, details of mining methods, and feasibility studies. MRDS has mineralogical and geologic data that are not contained in MAS. Because they are both mineral-resource data bases, however, they contain some information in common, such as location, name(s) of sites, and commodities present.

Both data bases are international in scope, and both are quite large. MRDS contains over 110,000 records, while MAS has over 220,000. One reason that MAS has more records is that it contains information on smelters, mill sites, and fossil fuel sites, as well as mineralresource sites. The USGS is working to combine the information in both data bases. This is a large undertaking that will require some years to complete. In the interim, information from both data bases will still be available.

\section{How Mineral-Resource Data Bases Are Used}

USGS scientists use mineral data in a variety of ways. One of the main activities of the USGS Mineral Resources Program is mineral-resource assessment of Federal lands, primarily at the request of the Bureau of Land Management (BLM) and the U.S. Forest Service. In order to better serve these land-managing Agencies, the USGS has conducted a prototype mineral-resource assessment of the conterminous United States. This project gives the USGS a good "head start" when asked to carry out a mineralresource assessment in a specific area.
By combining the information in the data bases (location, geologic setting, age of ore formation, and mineralogy) with other scientific information, such as geology, geophysics, and geochemistry, the USGS produced an assessment of undiscovered resources of gold, silver, copper, lead, and zinc . Maps such as that shown in figure 1 are one product of this assessment; the map in figure 1 depicts favorable areas for silver-rich deposits in the Great Basin. Products such as this map, when applied to National Forests or BLM Resource Areas, are valuable tools for land-use planning and for predicting of the level of exploration and mineral development likely to take place in the foreseeable future.
In addition to mineral-resource assessments, the USGS is conducting research on the environmental consequences of mining and is supplying scientific information needed to formulate plans for effective and costefficient remediation of abandoned mine lands.

Mine-land remediation is a problem of national scope. Although estimates vary, there is general agreement that hundreds of thousands of abandoned mines are scattered around the country. According to the General Accounting Office, over 14,000 of these sites need extensive remediation to stop acid and metal-rich drainage. Few dispute the Environmental Protection Agency's

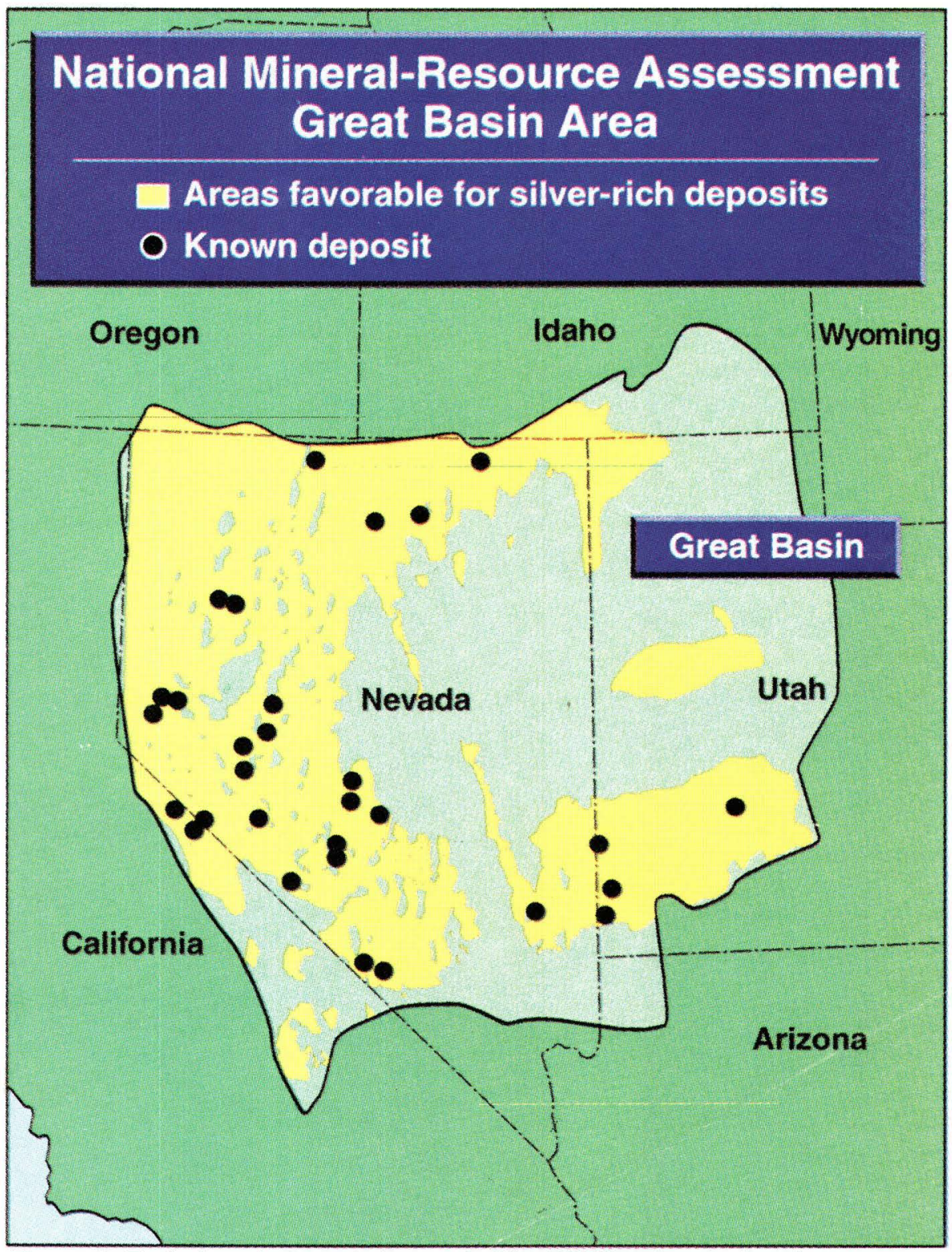

Figure 1. Typical product created as part of the USGS national mineral-resource assessment project. This map shows favorable areas for silver-rich deposits in the Great Basin area. 
prediction that it will take decades and billions of dollars to identify and reclaim every site that needs remediation (U.S. Environmental Protection Agency, 1996, Draft final hardrock mining framework: Washington, D.C., 66 p.)

Figure 2 shows the potential for acidic, metal-rich drainage from various types of abandoned mines in the upper Boulder

River basin in southwestern Montana. The USGS mineral-resource data bases played an important role in producing this model. The data in MRDS and MAS show that there are about 150 abandoned mines in the upper Boulder River basin and that the main metals mined were gold, silver, copper, lead, and zinc. In addition, the MAS data base contains information on mill and smelter sites, waste dumps, and tailings piles, which can also contribute significantly to contamination.

In addition to mineral information derived from MRDS and MAS, USGS scientists used regional data from geology, geochemistry, gravity, magnetics, radiometry, and remote sensing to derive the model. This model was an important element in helping the Bureau of Land Management, the U.S. Forest Service, and the State of Montana to prioritize the various watersheds in that State for remediation efforts. As a result, the Boulder River basin became a high priority for mitigation in Montana.

\section{Access to the Mineral-Resource Data Bases}

Access to the data bases is relatively easy, and the USGS is investigating ways to make it even easier. Both data bases are on CD-ROM (compact disc-readonly memory), and so anyone with a CDROM reader can access, search, and download any part of the data bases. In fiscal year 1997, the two data bases will be on a single CD-ROM. The USGS also will be placing parts of the data bases on the World Wide Web in 1998. Current plans are to update the CD-ROM yearly and the Web site as appropriate.

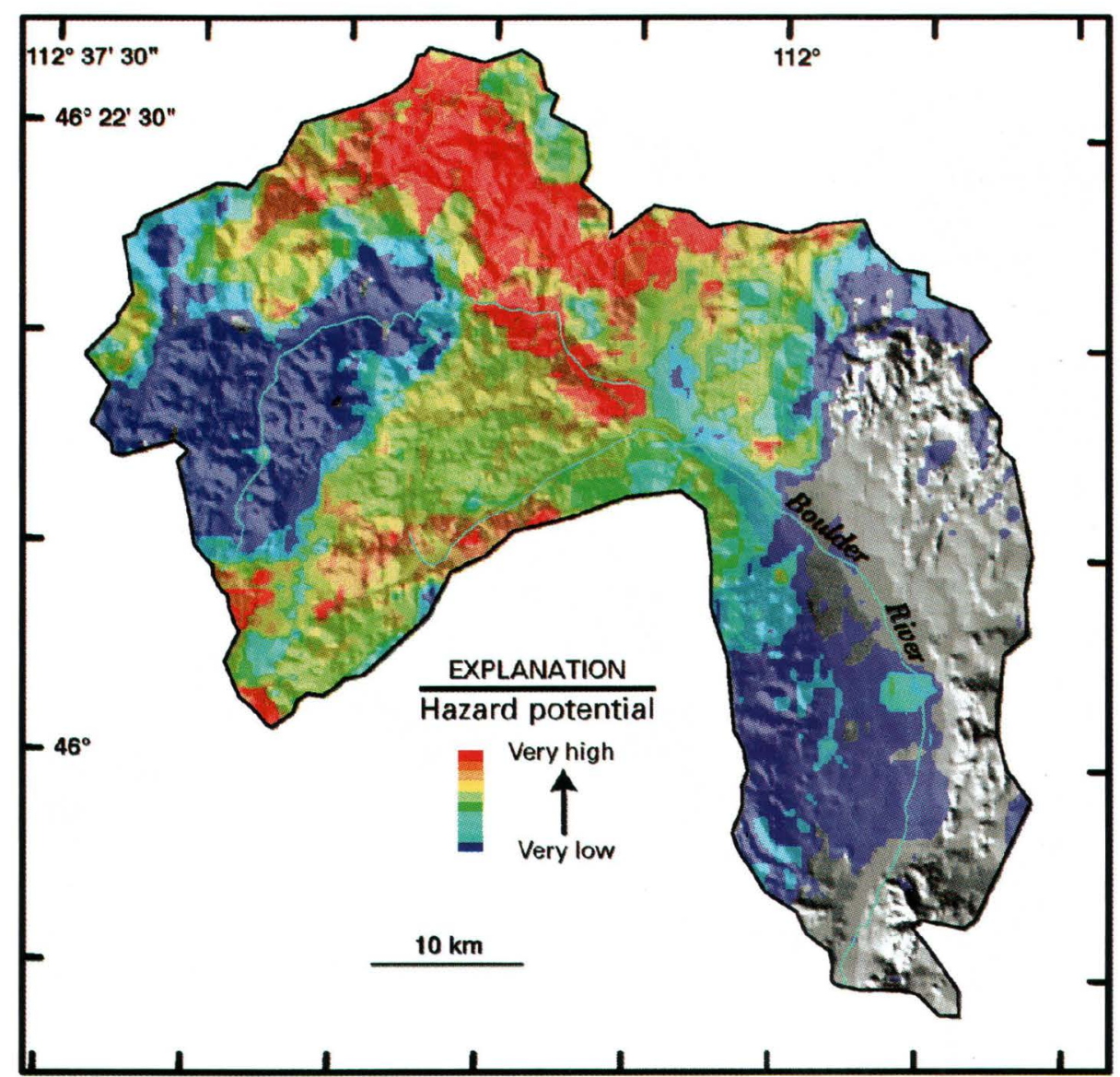

Figure 2. Geoenvironmental hazard potential for acidic, metal-rich drainage in the Boulder River basin, Montana.

For more information on MRDS, please contact:

Bruce R. Lipin

U.S. Geological Survey

954 National Center

Reston, VA 20192

Telephone: (703) 648-6430

E-mail: blipin@usgs.gov
For more information on MAS, please contact:

Donald Bleiwas

U.S. Geological Survey

P.O. Box 25046, MS 750

Denver, CO 80225

Telephone: (303) 236-8747, x340

E-mail: bleiwas@usgs.gov 